\title{
Morphological variability between populations of Neobythites stefanovi (Pisces: Ophidiidae) from the deep Red Sea and the Gulf of Aden
}

\author{
Franz Uiblein* \\ Konrad Lorenz-Institut für Vergleichende Verhaltensforschung, Austrian Academy of Sciences, Savoyenstr. 1a, \\ A-1160 Vienna, Austria
}

\begin{abstract}
The deep Red Sea represents a unique thermal environment with constantly high temperatures of about $21.5^{\circ} \mathrm{C}$ throughout the water column. In this warm ocean, secondary deep-sea fishes have colonized a wider vertical range than in adjacent areas of the Indo-Pacific. At great depths food availability is rather low, requiring distinctive morphological, physiological, or behavioural adaptations. In a quantitative morphological comparison, 2 populations of the ophidid species Neobythites stefanovi from the deep Red Sea and the adjacent Gulf of Aden were examined with respect to possible differences in 17 morphometric and 8 meristic characters. Both by univariate methods and by canonical variate analysis (CVA), considerable variations in 3 morphometric and 3 meristic characters were found. Accordingly, the Red Sea population shows a larger mouth and the ocellus on the dorsal fin has a vertically larger and more anteriorly positioned dark spot than that in the Gulf of Aden population. In accordance with earlier data on morphological variability between populations of the bythitid fish Oligopus robustus from the Red Sea and the Gulf of Aden, the larger mouth indicates an adaptation of foraging style to the low energetic returns in the deep Red Sea. The ocellus of $N$. stefanovi resembles that of other closely related Neobythites species in form, position, and size and most probably serves an antipredator function. The increased vertical size of the ocellus spot in the deeper-living, Red Sea population may intensify the signalling effect. A finding that deserves further investigation in other ocellus-bearing species is the population difference in spot position. The classification results of the CVA based on the morphometric and meristic data sets both confirm the existence of 2 morphologically divergent populations, but do not support earlier assumptions of a high intraspecific variability among deep-sea fishes from different parts of the Gulf of Aden.
\end{abstract}

KEY WORDS: Thermal environment - Deep-sea colonization - Nutritional conditions - Adaptive differentiation · Mouth size Foraging style - Ocellus function

\section{INTRODUCTION}

The Red Sea is an exceptionally warm ocean with uniform temperatures of about $21.5^{\circ} \mathrm{C}$ from some $200 \mathrm{~m}$ depth downwards to the deep-sea bottom at more than $2000 \mathrm{~m}$ depth (Fuchs 1901, Ekman 1953, Edwards 1987). Mainly due to these unique thermal conditions, the fauna living even in the deepest zones of the Red Sea consists of species which have recently

\footnotetext{
- Present address: Research Centre for Biosystematics and Ecology, Austrian Academy of Sciences, Kegelgasse 27/2, A-1030 Vienna, Austria; E-mail: uiblein@oeaw.ac.at
}

migrated from shallower levels (Balss 1931, Klausewitz 1986). In most other oceans, water temperature drops significantly with increasing depth; and, at greater depths, species originating from warmer coastal waters are replaced by secondary or primary deep-sea dwellers which may show considerable morphological differentiations (e.g. Marshall 1957, Gage \& Tyler 1991).

The particular thermal environment prevailing in the Red Sea may exert 2 different influences on deepsea colonizers: the isothermy allows a relatively wide distribution among different vertical habitats and facilitates colonization of empty niches, which in other oceans are occupied by cold-water-adapted species. 
This wide depth distribution becomes evident when populations of species living in both the Red Sea and adjacent waters of the Indo-Pacific are compared. Recent investigations have demonstrated that fish species from 7 different families occur in the Red Sea at depths of more than 700 and up to $1500 \mathrm{~m}$ and in the Gulf of Aden only at depths of less than $550 \mathrm{~m}$ (Klausewitz 1986, 1989, Krupp 1987, Nielsen \& Uiblein 1993, Klausewitz \& Uiblein 1994).

While isothermy may facilitate colonization of the deep Red Sea, the generally high temperature may also act as an indirect physiological constraint (Davenport \& Sayer 1993) because metabolic rate is kept at high level and food supply decreases significantly with increasing depth. The latter is due to a high decomposition rate of sinking organic matter which transports the energy necessary for secondary production from the surface to the deep-sea (Thiel 1979, Weikert 1982, Thiel et al. 1987, Pfannkuche 1993). In response to these particular conditions, invaders of the deep Red Sea may have to change their lifestyles. This is associated with distinctive morphological, physiological, or behavioural adjustments and has been confirmed by recent comparative studies on geographical variation among species with populations in the Red Sea and in the Gulf of Aden.

For instance, the tongue-sole Cynoglossus acutirostris Norman, 1939 occurs in the Red Sea at 712 to $1424 \mathrm{~m}$ depth and has been collected in the Gulf of Aden at $220 \mathrm{~m}$ depth. The Red Sea population shows a much smaller body size which may be best explained as a decrease in growth rate in response to the poor nutritional conditions in the deep Red Sea (Krupp 1987).

The bythitid Oligopus robustus (Smith \& Radcliffe, 1913) occurs in the Red Sea at 363 to $1258 \mathrm{~m}$ depth and in other parts of the Indopacific at 50 to $549 \mathrm{~m}$ depth (Klausewitz \& Uiblein 1994). The Gulf of Aden population can be distinguished statistically from the Red Sea population by several morphometric and meristic characters. The morphometric differences with larger mouths and heads in the Red Sea specimens indicate the adoption of an energy saving foraging style with a selective bias towards particularly large-sized prey types (Klausewitz \& Uiblein 1994). Because the Gulf of Aden specimens of $O$. robustus all originated from a single locality situated near the inflow of a warm, deep-water layer from the southern Red Sea, Klausewitz \& Uiblein (1994) underlined the necessity of examining additional material from other areas of the Gulf of Aden.

The ophidiid species Neobythites stefanovi Nielsen \& Uiblein, 1993 was recently discovered in the central Red Sea at depths between 4.34 and $804 \mathrm{~m}$ and in the Gulf of Aden at depths between 80 and $549 \mathrm{~m}$ (Nielsen \& Uiblein 1993). In this earlier study, the Red Sea specimens showed slight morphological differences from the Indian Ocean specimens, indicating a differentiation at the population level (Nielsen \& Uiblein 1993). Subadults and adults of $N$. stefanovi possess a conspicuous ocellus on the dorsal fin consisting of a blackish spot surrounded by a contrasting white ring. This ocellus possibly serves to deter visually hunting predators (Uiblein et al. 1994).

In the present study, I provide a quantitative morphological comparison of the 2 populations of $\mathrm{Neo}$ bythites stefanovi from the Red Sea and the Gulf of Aden based on measurements of 17 morphometric and eight meristic characters. Both univariate and multivariate methods are employed to detect significant differences between the 2 populations. These results are then discussed with the aim of detecting functional relationships between morphological and ecological variation. Particular interest concerns the possible functions of the ocellus.

\section{MATERIAL AND METHODS}

A total of 32 specimens of Neobythites stefanovi with 37 to $168 \mathrm{~mm}$ standard length (SL) were examined. In all specimens the ocellus had reached developmental stage 4 according to the scale provided by Uiblein et al. (1994), with a well developed dark spot and the surrounding white ring already well visible. Of the specimens, 15 originated from the central Red Sea and 17 from localities situated in the northwestern, central, and eastern part of the Gulf of Aden. A list including the material examined, a distribution map, and illustrations of $N$. stefanovi is given in Nielsen \& Uiblein (1993).

For each specimen, measurements of SL and 17 morphometric characters (all in $\mathrm{mm}$ ) were obtained using an electronic caliper. Counts of 8 meristic characters were also obtained using radiographs for the vertebral and median finray counts. The following is a list of all morphometric and meristic characters examined with additional explanations added.

Body depth: body depth at anus excluding dorsal fin; body width. body width behind pectoral base; predorsal length: distance between symphysis of upper jaw (SU) and anterior base of dorsal fin; prespot length: distance between SU and first ray covered by spot; preanal length: distance between SU and basis of anal fin; ventral-anal distance: distance between anterior bases of ventral and anal fins; prepectoral length: distance between SU and upper basis of pectoral fini ventral length: length of ventral fin; pectoral length: length of pectoral fin from upper basis of fin rays; head length: distance between SU and posterior edge of operculum; postorbital length: posterior margin of orbit to posterior edge of operculum; orbit length: horizontal length of or- 
bit; preorbital length: distance between SU and anterior margin of orbit; head depth: head depth just anterior to ventral fin base; interorbital distance: least distance between orbital margins; upper jaw length; lower jaw length: lower jaw length measured from the posterior extremity of upper jaw; dorsal rays; dorsal rays in front of anal: dorsal ray number counted to a vertical line from first anal ray; dorsal rays in front of spot; dorsal rays in spot: number of dorsal rays covered by spot; anal rays; scales in spot: scale rows below dorsal fin covered by spot; vertebrae: number of vertebrae including ural elements; gill rakers: long gill rakers only.

The morphometric characters were adjusted to size by running $\log -\log$ regressions between SL and each character (Reist 1985). The individual deviations from the regression functions ('residuals') were used in the subsequent uni- and multivariate comparisons. Oneway ANOVA was used to detect statistical differences between the 2 populations. To determine combined sets of variables with maximal separation among the 2 populations, canonical variate analysis (CVA) was carried out (Humphries 1990). This method also allowed determination of the likelihood of misclassification of fish from distinct collecting stations.
The 8 meristic characters were examined for size dependence using Spearman's rank correlation. To exclude effects from size differences among the 2 populations, this analysis was carried out for eacin population separately. The only significant correlation with SL was found for dorsal rays in spot in the Red Sea group $(\mathrm{n}=15, \mathrm{r}=-0.54, \mathrm{p}<0.05)$. Consequently, this character was excluded from the subsequent statistical procedures. The remaining 7 characters were examined for significant differences between the 2 groups using G-test. Subsequently, CVA was carried out following the same procedure as described for the morphometric characters.

In 20 of the 32 total specimens under investigation, sex could be determined ( 9 males and 11 females). No significant relationships between sex and the morphometric or meristic characters could be detected.

\section{RESULTS}

Means and ranges of the unstandardized morphometric and the meristic characters are given in Table 1. The allometric regressions between SL and the 17 mor-

Table 1. Neobythites stefanovi. Means \pm SD and ranges of the raw data including measurements of SL and 17 morphometric and 8 meristic characters in 2 populations

\begin{tabular}{|c|c|c|c|c|c|c|}
\hline & \multicolumn{3}{|c|}{ Red Sea $(n=15)$} & \multicolumn{3}{|c|}{ Gulf of Aden $(n=17)$} \\
\hline & Min & Mean $\pm \mathrm{SD}$ & Max & Min & Mean $\pm \mathrm{SD}$ & Max \\
\hline \multicolumn{7}{|c|}{ Morphometric characters (mm) } \\
\hline SL & 37 & $69.60 \pm 28.37$ & 122 & 42 & $123.47 \pm 42.86$ & 168 \\
\hline Body depth & 6.60 & $13.17 \pm 6.15$ & 25.51 & 6.84 & $25.26 \pm 9.71$ & 36.50 \\
\hline Body width & 2.62 & $6.67 \pm 3.32$ & 14.28 & 3.34 & $12.51 \pm 5.24$ & 20.47 \\
\hline Predorsal length & 10.15 & $18.06 \pm 7.43$ & 32.82 & 10.34 & $32.85 \pm 12.15$ & 47.02 \\
\hline Prespot length & 17.39 & $34.06 \pm 13.95$ & 60.79 & 20.79 & $65.30 \pm 23.82$ & 94.27 \\
\hline Preanal length & 14.39 & $27.61 \pm 11.43$ & 51.03 & 15.87 & $51.44 \pm 19.14$ & 74.87 \\
\hline Ventral-anal dist. & 8.30 & $16.81 \pm 6.57$ & 29.19 & 10.59 & $31.46 \pm 11.30$ & 44.95 \\
\hline Prepectoral length & 9.25 & $16.89 \pm 6.93$ & 31.87 & 10.57 & $30.60 \pm 11.50$ & 44.14 \\
\hline Ventral length & 6.35 & $11.85 \pm 4.88$ & 22.22 & 6.43 & $21.28 \pm 7.96$ & 31.62 \\
\hline Pectoral length & 5.42 & $9.62 \pm 3.50$ & 16.82 & 5.71 & $17.44 \pm 6.46$ & 25.94 \\
\hline Head length & 9.99 & $17.42 \pm 6.80$ & 31.55 & 10.12 & $31.27 \pm 11.69$ & 46.00 \\
\hline Postorbital length & 5.62 & $10.49 \pm 3.97$ & 18.26 & 6.51 & $19.19 \pm 7.09$ & 28.63 \\
\hline Orbit length & 1.76 & $4.14 \pm 1.70$ & 7.23 & 2.25 & $7.69 \pm 2.92$ & 11.50 \\
\hline Preorbital length & 2.04 & $3.83 \pm 1.62$ & 7.10 & 2.09 & $6.61 \pm 2.44$ & 10.26 \\
\hline Head depth & 6.86 & $12.33 \pm 5.24$ & 23.43 & 7.86 & $21.70 \pm 7.53$ & 31.19 \\
\hline Interorbital dist. & 1.95 & $3.56 \pm 1.38$ & 6.34 & 2.18 & $5.60 \pm 1.73$ & 7.90 \\
\hline Upper jaw length & 4.70 & $8.62 \pm 3.33$ & 15.46 & 5.17 & $14.35 \pm 4.95$ & 19.98 \\
\hline Lower jaw length & 4.35 & $8.10 \pm 3.05$ & 13.92 & 4.25 & $13.28 \pm 4.65$ & 18.72 \\
\hline \multicolumn{7}{|l|}{ Meristic characters } \\
\hline Dorsal rays & 89 & $91.20 \pm 1.33$ & 93 & 90 & $91.88 \pm 1.28$ & 94 \\
\hline In front of anal & 18 & $18.73 \pm 0.68$ & 20 & 17 & $19.65 \pm 1.14$ & 21 \\
\hline In front of spot & 21 & $23.27 \pm 1.65$ & 26 & 22 & $25.71 \pm 1.67$ & 29 \\
\hline In spot & 9 & $10.13 \pm 0.96$ & 12 & 8 & $9.65 \pm 1.37$ & 12 \\
\hline Anal rays & 73 & $75.07 \pm 1.18$ & 77 & 73 & $74.82 \pm 1.25$ & 78 \\
\hline Scales in spot & 0 & $2.33 \pm 1.14$ & 4 & 0 & $0.41 \pm 0.77$ & 3 \\
\hline Vertebrae & 53 & $53.80 \pm 0.91$ & 56 & 52 & $54.00 \pm 0.77$ & 55 \\
\hline Gill rakers & 10 & $11.53 \pm 0.72$ & 13 & 10 & $11.94 \pm 0.87$ & 13 \\
\hline
\end{tabular}


Table 2. Neobythites stefanovi. Means, F-values of ANOVA, and correlations with the canonical variate ( $r$ ) for the transformed values (multiplied by $10^{3}$ ) of 17 morphometruc characters (mm) in 2 populations ( $\mathrm{p}<0.05 ; \cdots p<0.02$ )

\begin{tabular}{|lrrrrr|}
\hline & $\begin{array}{r}\text { Red } \\
\text { Sea }\end{array}$ & $\begin{array}{c}\text { Gulf } \\
\text { of Aden }\end{array}$ & F-value & r \\
& & & & \\
\hline Body depth & -0.55 & 0.48 & $0.02 \mathrm{~ns}$ & -0.02 \\
Body width & 10.96 & -9.67 & $1.55 \mathrm{~ns}$ & 0.20 \\
Predorsal length & 1.28 & -1.13 & $0.15 \mathrm{~ns}$ & 0.06 \\
Prespot length & -7.69 & 6.78 & $7.33 \cdots$ & -0.44 \\
Preanal length & -2.08 & 1.83 & $0.44 \mathrm{~ns}$ & -0.11 \\
Ventral-anal dist. & -7.65 & 6.75 & $2.72 \mathrm{~ns}$ & -0.27 \\
Prepectoral length & 0.91 & -0.80 & $0.06 \mathrm{~ns}$ & 0.04 \\
Ventral length & 4.76 & -4.20 & $0.51 \mathrm{~ns}$ & 0.12 \\
Pectoral length & -2.11 & 1.86 & $0.08 \mathrm{~ns}$ & -0.04 \\
Head length & 2.59 & -2.28 & $0.54 \mathrm{~ns}$ & 0.12 \\
Postorbital length & -2.91 & 2.57 & $0.46 \mathrm{~ns}$ & -0.11 \\
Orbit length & 0.42 & -0.37 & $0.01 \mathrm{~ns}$ & 0.01 \\
Preorbital length & 7.59 & -6.70 & $0.89 \mathrm{~ns}$ & 0.15 \\
Head depth & -0.41 & 0.36 & $0.02 \mathrm{~ns}$ & -0.02 \\
Interorbital dist. & 7.55 & -6.66 & $0.82 \mathrm{~ns}$ & 0.15 \\
Upper jaw length & 7.69 & -6.78 & $4.55 \cdot$ & 0.35 \\
Lower jaw length & 1.1 .49 & -10.14 & 6.51 & $\cdots$ & 0.41 \\
\hline
\end{tabular}

phometric variables all showed strong correlations $(r>0.97)$ and were highly significant $(p<0.00001)$. The means of the size-adjusted, log-transformed values of the morphometric characters and the results of univariate $F$-tests are shown in Table 2 . Significant differences between the 2 populations were found in prespot length, upper jaw length, and lower jaw length. These 3 variables also showed the highest coefficients in the subsequent CVA (Table 2).

The means of the meristic values and the results of the G-tests are shown in Table 3. Significant differences between the 2 groups were found in dorsal rays in front of anal, dorsal rays in front of spot, and scales in spot (Fig. 1). These 3 variables also showed the highest coefficients in the subsequent CVA (Table 3). The number of dorsal rays in spot ranged between 8 and 12 with a large overlap between populations.
Table 3. Neobythites stefanovi. Means, G-values of G-tests and the correlations with the canonical variate (r) for 7 untransformed meristıc characters in 2 populations ( $p<0.05$; $\cdots p<0.021$

\begin{tabular}{|c|c|c|c|c|}
\hline & $\begin{array}{l}\text { Red } \\
\text { Sea }\end{array}$ & $\begin{array}{c}\text { Gulf } \\
\text { of Aden }\end{array}$ & G-value & $\mathrm{r}$ \\
\hline Dorsal rays & 91.20 & 91.88 & 4.45 ns & -0.19 \\
\hline In front of anal & 18.73 & 19.65 & $11.28^{\circ}$ & -0.36 \\
\hline In front of spot & 23.27 & 25.71 & $14.78^{\circ}$ & -0.55 \\
\hline Anal rays & 75.07 & 74.82 & 6.10 ns & 0.07 \\
\hline Scales in spot & 2.33 & 0.41 & $17.72 \cdots$ & 0.74 \\
\hline Vertebrae & 53.80 & 54.00 & $6.17 \mathrm{~ns}$ & -0.09 \\
\hline Gill rakers & 11.53 & 11.94 & 2.81 ns & -0.19 \\
\hline
\end{tabular}

The plotted scores of the CVA based on the 2 character sets are shown in Fig. 2. With respect to both the morphometric and the meristic characters, $90.63 \%$ of the individuals which had been initially assigned to 1 of the 2 populations were correctly classified. In both analyses only 1 of 8 specimens originating from the probably ecologically deviating locality in the northwestern part of the Gulf of Aden (see Klausewitz \& Uiblein 1994) was classified as belonging to the Red Sea group.

\section{DISCUSSION}

Both the univariate and the multivariate analyses clearly demonstrate an intraspecific morphological variation among the 2 populations of Neobythites stefanovi from the Red Sea and the Gulf of Aden. This variation mainly concerns measures related to mouth size and to position and size of the ocellus. Is this morphological variation a result of adaptive differentiation processes in response to the ecological differences between the Red Sea and the Gulf of Aden?

According to the jaw length measures, the Red Sea population has a larger mouth, which should allow intake of particularly large prey items. This finding corresponds with earlier results on local variation of

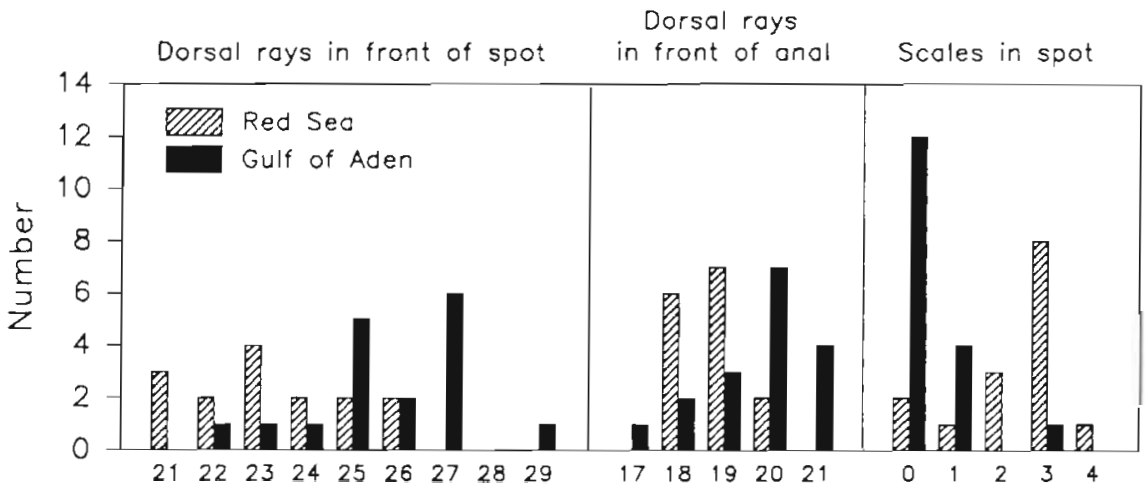

Fig. 1. Neobythites stefanovi. Frequency distribution for 3 meristic characters in 2 populations 


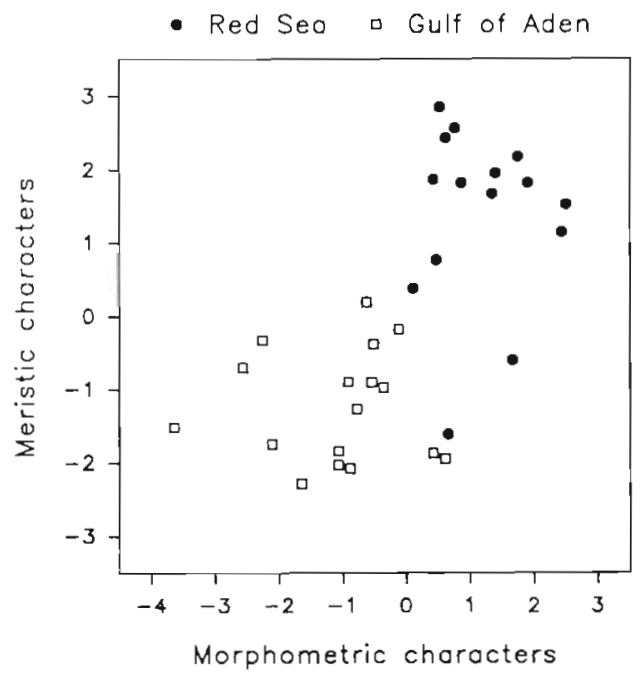

Fig. 2. Neobythites stefanovi. Plotted scores for the 2 canonical variates generated from 17 morphometric and 7 meristic characters of 2 populations (15 specimens from the Red Sea and 17 from the Gulf of Aden)

mouth size measures in Oligopus robustus from the Red Sea and the Gulf of Aden (Klausewitz \& Uiblein 1994). In that study, the authors suggested that the larger mouths reflect the adoption of an energy-saving foraging style in response to the specific ecological conditions of high metabolism and low food abundance in the deep Red Sea (Thiel 1979, Weikert 1982, Thiel et al. 1987, Pfannkuche 1993). Large mouths should be energetically rewarding because they enable fish to select prey over a wide size range and to increase operational prey density (Hyatt 1979. Schmitt $\&$ Holbrook 1984). Including the more profitable largesized prey in the diet may also allow an increase in the energetic payoff per unit food searching time (Stephens \& Krebs 1986).

Although food remains discovered in the guts of the Neobythites stefanovi specimens consisted mainly of crustacean prey, more specific identification of these remains was difficult and no conclusions on possible differences in prey size spectra could be drawn. Therefore, only data from morphological comparisons between the Red Sea and the Gulf of Aden populations of Oligopus robustus and $N$. stefanovi are currently available, and these data clearly suggest an adaptation in foraging style to the low energetic returns in the deep Red Sea.

The specific function of the ocellus of Neobythites stefanovi is not yet fully understood. Ocelli or eyespots have been discovered in many fish species (e.g. Breder 1972, Ehrlich 1975, Neudecker 1989). Several authors have suggested a signalling function of these eyeresembling structures related to predator avoidance (MCPhail 1977, Neudecker 1989, Altbäcker \& Csányi
1990, Winemiller 1990), to social communication (Kohda \& Watanabe 1990, Dawkins \& Guilford 1994) or to both factors (Nursall 1973, Meadows 1993).

In a recent study on vertical distribution and ocellus development in Neobythites stefanovi from the Red Sea, the possible antipredator function of this structure was emphasized (Uiblein et al. 1994). Accordingly, older and larger specimens which already possess a well developed ocellus migrate from depths of about $800 \mathrm{~m}$ upwards into shallower zones of less than $600 \mathrm{~m}$ depth. There they encounter more food, but also a higher number of predators. The ocellus may allow $N$. stefanovi to cope with this increased predation pressure by deflecting predatory attacks to less vital parts of the body (Neudecker 1989, Winemiller 1990) or by deterring predators from further pursuit (Hasson 1991).

There is no indication that Neobythites stefanovi uses the ocellus for social communication. Both sexes show a well developed ocellus and the closely related $N$. steatiticus which co-accurs with $N$. stefanovi in the Gulf of Oman also has an ocellus on the dorsal fin which is very similar in shape, size, and position (J. G. Nielsen pers comm.; see also Alcock 1893). A comparable ocellus on the dorsal fin can be found in other Neobythites species, too (Kamohara 1954, Nielsen 1995). Consequently, this structure in particular should not play a significant role in mate or species recognition. Social communication may be achieved by use of other visual or non-visual signalling devices. For instance, $N$. stefanovi and $N$. steatiticus differ from each other in coloration of dorsal fin and body (Nielsen \& Uiblein 1993). Moreover, ophidiiform species frequently have swimbladders with attached muscles which can be used as drumming organs and may allow auditory recognition of conspecifics or communication between sexes (Mead et al. 1964, Courtenay 1971).

In Neobythites stefanovi, the spot of the ocellus is more than twice as long as the horizontal eye window (cf. Nielsen \& Uiblein 1993). Probably due to the formation of the surrounding ring, the length of the spot decreases somewhat in Red Sea specimens during ontogeny but always remains within the size range of the Gulf of Aden population. With respect to the depth of the spot, however, clear population differences can be detected. In the Red Sea population the spot expands vertically and covers a higher number of horizontal scale rows. Under weak illumination conditions, such as at night or in dusky environments, the presentation of large spots may be especially effective (Neudecker 1989, Endler 1992). An examination of the depth distribution data from all of the $N$. stefanovi material available (52 specimens from 21 localities, cf. Nielsen \& Uiblein 1993) clearly shows that this species 
occurs in the Red Sea at much greater depths than in the Gulf of Aden (434 to 801 and 80 to $549 \mathrm{~m}$ respectively). The increased vertical size of the spot may thus reflect an adaptation to the lower light intensity at greater depths.

With the ocellus placed on the dorsal fin Neobythites stefanovi may be capable of suddenly unfolding and presenting this structure, thus catching the attention of approaching signal receivers (see also Dawkins \& Guilford 1994). In the Red Sea population, the spot of the ocellus is placed more anteriorly than in the Gulf of Aden population. To my knowledge, this finding provides the first indication of intraspecific local variation in ocellus position in fishes. Because this difference is rather small, it should have no crucial effect on ocellus recognition. For a proper evaluation of a possible functional significance of this result, collecting of comparable data from other ocellus-bearing fish species will be necessary.

It follows from the classification results of the CVA that the specimens from the 2 different populations are morphologically divergent and that the within-population variability in morphometric and meristic characters is comparatively low. In both analyses, 7 of the 8 specimens from the northwestern Gulf of Aden were correctly classified, indicating a much lower affinity with conspecifics living in the central Red Sea than with those from other areas of the Gulf of Aden. Therefore, these data do not substantiate earlier assumptions of a high intraspecific variability among deep-sea dwellers from the northwestern part and other localities of the Gulf of Aden (Klausewitz \& Uiblein 1994).

Morphological variability among spatially and ecologically separated fish populations may be induced by genetically manifested polymorphisms or by phenotypic plasticity (Wimberger 1991, 1992). Recent comparative studies on fish species belonging to the families Cyprinidae and Mullidae have suggested that phenotypic plasticity in body form contributes to a considerable extent to intraspecific morphological variability (Uiblein \& Winkler 1994, Uiblein et al. in press). Klausewitz \& Uiblein (1994) found a high variability in morphometric characters of Oligopus robustus between the 2 populations from the Red Sea and the Gulf of Aden, as well as among Red Sea specimens from different depths. This latter result was confirmed by a study on depth-related morphological variability of the Red Sea population of O. robustus (Uiblein et al. 1994). Most of the specimens examined originated from localities which were only a few kilometres apart. Gene flow between these localities should be rather frequent and the authors assumed that the high morphological variability among $O$. robustus may be at least partially caused by phenotypic plasticity in body shape (Klausewitz \& Uiblein 1994, Uiblein et al. 1994).
Acknowledgements. My special thanks go to Jorgen Nielsen for his help with the measurements and for his hospitality during my stays at the Zoological Museum, University of Copenhagen. Nigel Merrett and Jørgen Nielsen provided valuable comments on an earlier draft of the manuscript.

\section{LITERATURE CITED}

Alcock A (1893) Natural history notes from $H$. M. survey steamer 'Investigator' Commander C. F. Oldham, R. N., commanding. Series II, No. 9. An account of the deep sea collection made during the season of 1892-1893. J Asiatic Soc Bengal 62:179-184

Altbäcker V, Csányi V (1990) The role of eyespots in predator recognition and antipredator behaviour of the paradise fish, Macropodus opercularis L. Ethology 85:51-57

Balss H (1931) Expedition S.M. Schiff 'Pola' in das Rote Meer, nördliche und südliche Hälfte 1895/96-1987/98. Zoologische Ergebnisse. XXXVI. Decapoden des Roten Meeres IV. Oxyrhyncha und Schlußbetrachtungen. Denkschr Öster I Akad Wiss, math nat Klasse 102:1-30

Breder C M (1972) On the relationship of teleost scales to pigment patterns. Contr Mote mar Lab 1:1-79

Courtenay W R (1971) Sexual dimorphism of the sound producing mechanism of the striped cusk-eel, Rissola marginata (Pisces: Ophidiidae). Copeia 1971:259-268

Davenport J, Sayer MDJ (1993) Physiological determinants of distribution in fish. J Fish Biol (Suppl A) 43:121-145

Dawkins MS, Guilford T (1994) Design of an intention signal in the bluehead wrasse (Thalassoma bifasciatum). Proc $\mathrm{R}$ Soc B257:123-128

Edwards FJ (1987) Climate and oceanography. In: Edwards AJ, Head SM (eds) Key environments. Red Sea. Pergamon Press, Oxford, p 45-69

Ehrlich PR (1975) The population biology of coral reef fishes. A Rev Ecol Syst 6:211-247

Ekman S (1953) Zoogeography of the sea. Sidgwick and Jackson, London

Endler JA (1992) Signals, signal conditions, and the direction of evolution. Am Nat 139(Suppl):125-153

Fuchs T (1901) Über den Charakter der Tiefseefauna des Roten Meeres auf Grund der von den österreichischen Tiefsee-Expeditionen gewonnenen Ausbeute. Sitzber Österr Akad Wiss, math naturwiss Klasse 110:249-258

Gage JD, Tyler PA (1991) Deep sea biology. Cambridge University Press, Cambridge

Hasson O (1991) Pursuit-deterrent signals: communication between prey and predator. TREE 6:325-329

Humphries P (1990) Morphological variation in diadromous and landlocked populations of the spotted galaxes, Galaxias truttaceus, in Tasmania, south-eastern Australia. Environ Biol Fish 27:97-105

Hyatt KD (1979) Feeding strategy. In: Hoar WS, Brett JR (eds) Fish physiology, Vol VIII. Academic Press, London

Kamohara T (1954) A review of the family Brotulidae found in the waters of Prov. Tosa, Japan. Rep USA mar biol Stn, Kochi Univ (Kochi-Ken, Japan) 1:1-14

Klausewitz W (1986) Zoogeographic analysis of the vertical distribution of the deep Red Sea ichthyofauna, with a new record. Senckenbergiana Marit 17:279-292

Klausewitz W (1989) Evolutionary history and zoogeography of the Red Sea ichthyofauna. Fauna Saudi Arabia 10: $311-337$

Klausewitz W, Uiblein F (1994) Tiefenwasser- und Tiefseefische aus dem Roten Meer. XVII. Oligopus robustus, a new record for the Red Sea, with comparative studies on 
specimens from the Gulf of Aden. Senckenbergiana Marit $25: 21-28$

Kohda Y, Watanabe M (1990) The aggression-releasing effect of the eye-like spot of the oyanirami Coreoperca kawamebari, a freshwater serranid fish. Ethology 84:162-166

Krupp F (1987) Tiefenwasser- und Tiefseefische aus dem Roten Meer XV. The occurrence of Cynoglossus acutirostris Norman 1939 in the Red Sea. Senckenbergiana Marit 19:249-259

Marshall NB (1957) Tiefseebiologie. Gustav Fischer Verlag, Jena

McPhail JD (1977) A possible function of the caudal spot in characid fishes. Can J Zool 55:1063-1066

Mead GW, Bertelsen E, Cohen DM (1964) Reproduction among deep-sea fishes. Deep Sea Res 11:569-596

Meadows DW (1993) Morphological variation in eye-spots of the foureye butterflyfish (Chaetoton capistratus): implications for eyespot function. Copeia 1993:235-240

Neudecker S (1989) Eye camouflage and false eyespots chaetodontid responses to predators. Environ Biol Fish 25 $143-157$

Nielsen JG (1995) A review of the species of the genus Neobythites (Pisces, Ophidiidae) from the Western Indian Ocean with description of seven new species. Ichthyological Bull JLB Smith Inst Ichthyology 62:1-19

Nielsen JG, Uiblein F (1993) Tiefenwasser- und Tiefseefische aus dem Roten Meer. XVI. A new species of Neobythites from the NW Indian Ocean and the Red Sea. Senckenbergiana Marit 23:109-113

Nursall JR (1973) Some behavioural interactions of spottail shiners (Notropis hudsonius), yellow perch (Perca flavesCens), and northern pike (Esox lucius). J Fish Res Bd Can 30:1161-1178

Pfannkuche $O$ (1993) Benthic standing stock and metabolic activity in the bathyal Red Sea from $17^{\circ} \mathrm{N}$ to $27^{\circ} \mathrm{N}$. Mar Ecol 14:67-79

Reist JD (1985) An empirical evaluation of several univariate

This article was submitted to the editor methods that adjust for size variation in morphometric data. Can J Zool 63:1429-1439

Schmitt RJ, Holbrook SJ (1984) Gape-limitation, foraging tactics and prey size selectivity of two microcarnivorous species of fish. Oecologia 63:6-12

Stephens DW, Krebs JR (1986) Foraging theory. Princeton Univ Press, Princeton, NJ

Thiel $H$ (1979) First quantitative data on Red Sea deep benthos. Mar Ecol Prog Ser 1:347-350

Thiel H, Pfannkuche O, Thegg R, Schnever G (1987) Benthic metabolism and standing stock in the central and northern deep Red Sea. Mar Ecol 8:1-20

Uiblein F, Köhler C, Tian MC (in press) Quantitative examination of morphological variability among goatfishes of the genus Upeneus from the Malayan province. Senckenbergiana Marit

Uiblein F, Nielsen JG, Klausewitz W (1994) Depth dependent morphological variation in two ophidiiform fishes from the deep Red Sea: evidence for species-specific structure in vertical distribution. Cybium 18:15-23

Uiblein F, Winkler H (1994) Morphological variability among Vimba in Austrian waters: quantitative examination of a taxonomic and a functional hypothesis. Senckenbergiana Biol 73:57-65

Weikert $H$ (1982) The vertical distribution of zooplankton in relation to habitat zones in the area of the Atlantis II Deep, central Red Sea. Mar Ecol Prog Ser 8:129-143

Wimberger PH (1991) Plasticity of jaw and skull morphology in the neotropical cichlids Geophagus brasiliensis and $G$. steindachneri. Evolution 45:1545-1561

Wimberger PH (1992) Plasticity of fish body shape. The effects of diet, development, family and age in two species of Geophagus (Pisces: Cichlidae). Biol J Linn Soc 45: $197-218$

Winemiller KO (1990) Caudal eyespots as deterrents against fin predation in the neotropical cichlid Astronotus ocellatus. Copeia 1990:665-673

Manuscript first received: December 5, 1994

Revised version accepted: March 8, 1995 